of using DUR letter interventions to improve physician prescribing of AUAs. ${ }^{15,16}$

Funding for this research was provided by the New Mexico Medicaid Program. The authors acknowledge the support and assistance provided by Janet Hollarbush, BS, Leslie McCamentMann, BS, and the members of the New Mexico Medicaid Drug Utilization Review Board.

\section{REFERENCES}

1. Scherwitz L, Hennrikus D, Yusim S, Lester J, Vallbona C. Physician communication to patients regarding medications. Patient Educ Counseling. 1985;7:121-36.

2. Wiederholt JB, Clarridge BR, Svarstad BL. Verbal consultation regarding prescription drugs: findings from a statewide study. Med Care. 1992;30(2):159-73.

3. Makoul G, Arntson P, Schofield T. Health promotion in primary care: physician-patient communication and decision about prescription medications. Soc Sci Med. 1995;41(9):1241-54.

4. Nightingale $\mathrm{S}$. Do physicians tell patients enough about prescription drugs? Do patients think so? Postgrad Med. 1983;74(2): 169-75.

5. Kessler D. Communicating with patients about their medications. N Engl J Med. 1991;325(23):1650-2.

6. Rucker TD, Schiff G. Drug formularies: myths-in-formation. Med Care. 1990;28:928-35.

7. Soumerai SB, Avorn JL, Ross-Degnan D, Gortmaker S. Payment restrictions for prescription drugs under Medicaid: effects on therapy, cost, and equity. N Engl J Med. 1987;317:550-62.
8. Lipton HL, Bird JA. Drug utilization review in ambulatory settings: state of the science and directions for outcomes research. Med Care. 1993;31(12):1069-82.

9. Kreiling DK, Mott DA. The cost effectiveness of drug utilization review in an outpatient setting. Pharmacoeconomics. 1993;6:414-36.

10. Soumerai SB, McLaughlin TJ, Avorn J. Improving drug prescribing in primary care: a critical analysis of the experimental literature. Milbank Q. 1989;67:268-317.

11. Raisch D. Determinants of prescribing behavior. In: Smith MC, Wertheimer AI, eds. Social and Behavioral Aspects of Pharmaceutical Care. New York, NY: Pharmaceutical Products Press; 1996: 149-84.

12. Brodie DC. Drug utilization review/planning. Am J Public Health. 1972;46:103-10.

13. Palumbo FB. Drug use review under OBRA '90. US Pharmacist. 1993;18:86-90.

14. Lipowski E, Collins T. Medicaid DUR Programs 1993. Final Report. Washington, DC: American Pharmaceutical Association; September 1995.

15. Zimmerman DR, Collins TM, Lipowski EE, Sainfort F. Evaluation of a DUR intervention: a case study of histamine antagonists. Inquiry. 1994;31:89-101.

16. Rascati KL, Okano GJ, Burch C. Evaluation of physician intervention letters. Med Care. 1996;34(8):760-6.

17. Sherman DS, Avorn J, Campion E. Cimetidine use in nursing homes: prolonged therapy and excessive doses. J Am Geriatr Soc. 1987;35(11):1023-7.

18. Houston LJ, Mills JG, Wood JR. Does co-prescription of sulcrafate with ranitidine therapy enhance the healing of gastric ulcers. Am J Gastroenterol. 1993;88:675-84.

19. Siegel S, Castellan NJ Jr. Two independent samples. In: Nonparametric Statistics for the Behavioral Sciences. 2nd ed. New York, NY: McGraw Hill; 1988:102-67.

\title{
CALL FOR REVIEWER INFORMATION
}

We are updating our reviewer database. If you are presently reviewing manuscripts for JGIM or are willing to do so, please take a minute to complete the JGIM Reviewer Information Form at the end of this issue and fax it to (215) 823-4450. 